\title{
About the implementation and some applications of the FIXPOINT software minipackage
}

\author{
ANDREI BOZANTAN and VASILE BERINDE
}

\section{ABSTRACT.}

The main aim of this note is to briefly present the implementation, main features and some current and potential applications of the software minipackage FIXPOINT, designed and implemented by the first author and used by the second author in solving some concrete problems.

Acknowledgements. The second author's research was supported by the Grants PN-II-RU-TE-2011-3-239 and PNII-ID-PCE-2011-3-0087 of the Romanian Ministry of Education and Research.

\section{REFERENCES}

[1] Akbulut, S. and Zdemir, M., Picard iteration converges faster than Noor iteration for a class of Quasi-contractive operators, Chiang Mai J. Sci., 39 (2012), No. 4, 688-692

[2] Alotaibi, A., Kumar, V. and Hussain, N., Convergence comparison and stability of Jungck-Kirk-type algorithms for common fixed point problems, Fixed Point Theory Appl., 2013, 2013:173, 30 pp

[3] Babu, G. V. R. and Vara Prasad, K. N. V. V., Mann iteration converges faster than Ishikawa iteration for the class of Zamfirescu operators, Fixed Point Theory Appl, 2006, Art. ID 49615, 6 pp

[4] Babu, G. V. R. and Vara Prasad, K. N. V. V., Erratum: "Mann iteration converges faster than Ishikawa iteration for the class of Zamfirescu operators" [Fixed Point Theory Appl. 2006, Art. ID 49615, 6 pp.; MR2210912], Fixed Point Theory Appl, 2007, Art. ID 97986, 2 pp

[5] Babu, G. V. R. and Vara Prasad, K. N. V. V., Comparison of fastness of the convergence among Krasnoselskij, Mann, and Ishikawa iterations in arbitrary real Banach spaces, Fixed Point Theory Appl., 2006, Art. ID 35704, 12 pp

[6] Berinde, V., Iterative Approximation of Fixed Points, Efemeride Publishuing House, Baia Mare, 2002

[7] Berinde, V., Picard iteration converges faster than Mann iteration for a class of quasi-contractive operators, Fixed Point Theory Appl, 2004, No. 2, 97-105

[8] Berinde, V. and Berinde, M., The fastest Krasnoselskij iteration for approximating fixed points of strictly pseudo-contractive mappings, Carpathian J. Math., 21 (2005), No. 1-2, 13-20

[9] Berinde, V., Iterative Approximation of Fixed Points, 2nd edition, Springer, Berlin Heidelberg New York, 2007

[10] Berinde, V. and Păcurar, M., Empirical study of the rate of convergence of some fixed point iterative methods, Proc. Appl. Math. Mech., 7 (2007), 20300152030016. doi: 10.1002/pamm.200700254

[11] Berinde, V. and Păcurar, M., An iterative method for approximating fixed points of Prešić nonexpansive mappings, Rev. d'Anal. Numer. Theor. Approx., 38 (2009), No. 2, 144-153

[12] Berinde, V. and Păcurar, M., Two elementary applications of some Prešić type fixed point theorems., Creat. Math. Inform., 20 (2011), No. 1, 32-42

[13] Berinde, V. and Păcurar, M., O metodă de tip punct fix pentru rezolvarea sistemelor ciclice, Gazeta Matematică, Seria B, 116 (2011), No. 3, 113-123

[14] Berinde, V. and Păcurar, M., Stability of k-step fixed point iterative methods for some Prešić type contractive mappings, J. Ineq. Appl., 2014, 2014:149

[15] Bozantan, A., Algorithms for approximating fixed points, Dissertation Thesis, North University of Baia Mare, 2007

[16] Bozantan, A., An implementation of the piecewise-linear homotopy algorithm for the computation of fixed points, Creat. Math. Inform., 19 (2010), No. 2, 140-148

[17] Cegielski, A., Iterative Methods for Fixed Point Problems in Hilbert Spaces, Lecture Notes in Mathematics, 2057, Springer-Verlag, Berlin, 2013

[18] Chen, Y.-Z., A Prešić type contractive condition and its applications, Nonlinear Anal., 71 (2009), No. 12, 2012-2017

[19] Chidume, C. E., Geometric Properties of Banach Spaces and Nonlinear Iteration, Springer, Berlin Heidelberg New York, 2009

[20] Duong V. T., The comparison of the convergence speed between Picard, Mann, Ishikawa and two-step iterations in Banach spaces, Acta Math. Vietnam, 37 (2012), No. 2, 243-249

[21] Hussain, N., Rafiq, A., Damjanović, B. and Lazović, R., On rate of convergence of various iterative schemes., Fixed Point Theory Appl., 2011, 2011:45, 6 pp

[22] Hussain, N., Chugh, R., Kumar, V. and Raffia, A., On the rate of convergence of Kirk-type iterative schemes, J. Appl. Math, 2012, Art. ID 526503, 22 $\mathrm{pp}$

[23] Hussain, N., Kumar, V. and Kutbi, M. A., On rate of convergence of Jungck-type iterative schemes., Abstr. Appl. Anal., 2013, Art. ID 132626, 15 pp

[24] Kang, S. M., Ćirić, L. B., Rafiq, A., Ali, F., and Kwun, Y. C., Faster Multistep Iterations for the Approximation of Fixed Points Applied to Zamfirescu Operators, Abstr. Appl. Anal., Vol. 2013

[25] Karahan, I. and Murat, O., A general iterative method for approximation of fixed points and their applications, Adv. Fixed Point Theory, 3 (2013), No. $3,510-526$

[26] Khan, A. R., Kumar, V. and Hussain, N., Analytical and numerical treatment of Jungck-type iterative schemes, Appl. Math. Comput., 231 (2014), 521535

[27] Kumar, V., Comments on convergence rates of Mann and Ishikawa iterative schemes for generalized contractive operators, Int. J. Math. Anal. (Ruse), 7 (2013), No. 25-28, 1317-1321

[28] Olaleru, J. O., A comparison of Picard and Mann iterations for quasi-contraction maps, Fixed Point Theory, 8 (2007), No. 1, 87-95

[29] Olaleru, J. O., On the convergence rates of Picard, Mann and Ishikawa iterations of generalized contractive operators, Stud. Univ. Babeş-Bolyai Math, 54 (2009), No. 4, 103-114

Received: 25.05.2014; In revised form: 26.05.2014; Accepted: 02.06.2014

2010 Mathematics Subject Classification. 47H10, 47J25, 49M15, 49M30.

Key words and phrases. Fixed point, piecewise linear, homotopy, algorithm, implementation, optimization problem, Schwefel's function. 
[30] Păcurar, M., Approximating common fixed points of Prešić-Kannan type operators by a multi-step iterative method, An. Ştiinţ,. Univ. "Ovidius" Constanţa Ser. Mat., 17 (2009), No. 1, 153-168

[31] Păcurar, M., Iterative Methods for Fixed Point Approximation, Risoprint, Cluj-Napoca, 2010

[32] Păcurar, M., A multi-step iterative method for approximating fixed points of Prešić-Kannan operators, Acta Math. Univ. Comen. New Ser., 79 (2010), No. $1,77-88$

[33] Păcurar, M., A multi-step iterative method for approximating common fixed points of Prešić-Rus type operators on metric spaces, Stud. Univ. BabeşBolyai Math., 55 (2010), No. 1, 149-162

[34] Păcurar, M., Fixed points of almost Prešić operators by a k-step iterative method, An. Ştiint,. Univ. Al. I. Cuza Iaşi, Ser. Noua, Mat., 57 (2011), Supliment 199-210

[35] Păcurar, M., Common fixed points for almost Presić type operators, Carpathian J. Math., 28 (2012), No. 1, 117-126

[36] Phuengrattana, W. and Suantai, S., Strong convergence theorems and rate of convergence of multi-step iterative methods for continuous mappings on an arbitrary interval, Fixed Point Theory Appl., 2012, 2012:9

[37] Popescu, O., Picard iteration converges faster than Mann iteration for a class of quasi-contractive operators, Math. Commun., 12 (2007), No. 2, 195-202

[38] Rhoades, B. E. and Xue, Z., Comparison of the rate of convergence among Picard, Mann, Ishikawa, and Noor iterations applied to quasicontractive maps, Fixed Point Theory Appl, 2010, Art. ID 169062, 12 pp

[39] Xue, Z., The comparison of the convergence speed between Picard, Mann, Krasnoselskij and Ishikawa iterations in Banach spaces, Fixed Point Theory Appl, 2008, Art. ID 387056, 5 pp

[40] Xue, Z. and Rhoades, B. E., Comparison of the rate of convergence among Picard, Mann, Ishikawa, and Noor iterations applied to quasicontractive maps, Fixed Point Theory Appl., 2010, Art. No. 169062

\author{
Department OF MATHEMATICS AND COMPUTER SCIENCE \\ NORTH UNIVERSITY CENTER AT BAIA MARE \\ TECHNICAL UNIVERSITY OF CLUJ-NAPOCA \\ Victoriei 76, 430122, BAIA MARE, ROMANIA \\ E-mail address: andrei.bozantan@gmail.com \\ E-mail address: vberinde@ubm. ro
}

